\title{
Postganglionic Autonomic Fiber
}

National Cancer Institute

\section{Source}

National Cancer Institute. Postganglionic Autonomic Fiber. NCI Thesaurus. Code C12648.

An axon that projects from a nerve cell body within an autonomic ganglion and

innervates an effector cell within a target organ. 